\title{
Phenotypic variance of black oat growing in crop seasons reveals genetic effects predominance
}

\section{DANIELA MEIRA ${ }^{1}$, CARINE MEIER ${ }^{1}$, TIAGO OLIVOTO ${ }^{2}$, MAICON NARDINO ${ }^{3}$, ALEXSANDER RIGATTI $^{1}$, LUÍS ANTÔNIO KLEIN ${ }^{1}$, BRAULIO O. CARON ${ }^{1}$, VOLMIR S. MARCHIORO ${ }^{1}$ and VELCI Q. DE SOUZA ${ }^{4}$}

\author{
${ }^{1}$ Universidade Federal de Santa Maria, Departamento de Ciências Agrárias e Ambientais, \\ Rua 7 de Setembro, s/n, 98400-000 Frederico Westphalen, RS, Brazil \\ ${ }^{2}$ Universidade Federal de Santa Maria, Departamento de Ciências Agrárias, Av. \\ Roraima, 1000, Camobi, 97105-900 Santa Maria, RS, Brazil \\ ${ }^{3}$ Universidade Federal de Viçosa, Departamento de Fitotecnia, Av. P.H. Rolfs, s/n, 36571-000 Viçosa, MG, Brazil \\ ${ }^{4}$ Programa de Pós-Graduação em Ciências Biológicas, Universidade Federal do Pampa, Av. \\ 21 de Abril, 80, São Gregório, 96450-000 Dom Pedrito, RS, Brazil
}

Manuscript received on January 15, 2018; accepted for publication on August 21, 2019

\begin{abstract}
How to cite: MEIRA D, MEIER C, OLIVOTO T, NARDINO M, RIGATTI A, KLEIN LA, CARON BO, MARCHIORO VS AND SOUZA VQ. 2019. Phenotypic variance of black oat growing in crop seasons reveals genetic effects predominance. An Acad Bras Cienc 91: e20180036. DOI 10.1590/0001-3765201920180036.
\end{abstract}

\begin{abstract}
This work aimed to determine variance components and genetic parameters, as well as phenotypic, genetic and environmental correlations among black oat (Avena strigosa) families grown in different crop season. Seventy-six black oat families and three controls (BRS Madrugada, BRS Centauro, BRS 139 Neblina) were evaluated in two crop seasons (2016 and 2017), using families with intercalary controls experimental design. The results reveled high potential of black oat families to compose a breeding program, due to families and controls variance were similar, variance components expressed greater genetic variance origin for crop season. Panicle weight and panicle grain weight presented high heritability and, these are correlated with panicle length. Thus, these traits can be used to select superior genotypes. Divergent meteorological conditions between crop seasons expressed few variations among phenotypic, genetic and environmental correlations, and it did not alter magnitude and sense of phenotypic and genetic correlations.
\end{abstract}

Key words: Avena strigosa, genetic correlation, genetic parameters, plant breeding.

\section{INTRODUCTION}

Recognized among the major winter cereals, black oat (Avena strigosa S.) is cultivated worldwide. Its cultivation includes grain yield, forage and mainly soil cover. Despite developmental plasticity over a wide temperature range varying from $0{ }^{\circ} \mathrm{C}$ to $35^{\circ} \mathrm{C}$

Correspondence to: Daniela Meira

E-mail: dmdanielameira94@gmail.com

ORCid: https://orcid.org/0000-0001-7843-4472
(Leite et al. 2012). This crop is directly influenced by photoperiod and air temperature, and it can be observed cycle (Castro et al. 2012, Leite et al. 2012) and yield variations according to meteorological conditions (Ferris et al. 1998).

The genotypes $\mathrm{x}$ environments $(\mathrm{G} \times \mathrm{E})$ interaction may vary according to sowing season, local and crop season, favoring the complexity of this interaction, showing that direct selection for yield may be mistaken (Bennett et al. 2012, Rebetzke et 
al. 2012). To quantify this environmental influence, Cruz et al. (2014) emphasize that it is necessary to consider that phenotypic expression of a given trait is a result of genetic plus environment effect, and if grown in more than one environment, $\mathrm{G} \times \mathrm{E}$ interaction effect is added.

Plant breeding programs have increasingly searched oat genotypes with high potential for forage and grain yield. Artificial selection practice to obtain genotypes with high performance, can contributes to genetic variability reduction. Base population characterization of breeding program, in terms of genetic components, becomes relevant to maximize genetic gains (Pereira and Amaral Jr 2001). Obtaining estimates of variance components and genetic parameters can be achieved with phenotypic evaluations of interest traits (Cruz et al. 2014).

Phenotypic correlation include genetic and environmental effects, so may be stratify each one to better understand correlations. Associations knowledge between traits makes it possible to develop the best selection strategy and from covariances, to estimate selection indexes (Cruz et al. 2014). In addition, the magnitude and sense of correlations reveal association degree and sense between traits, indicating if there is a change in behavior in function of another trait.

Faced with hypotheses formulated: (i) two crop seasons can lead to divergent phenotypic, genetic and environmental variances; (ii) selection made in only one crop season is efficient if it was based on variance components; the study aimed to determine the variance components and genetic parameters, as well as phenotypic, genetic and environmental correlations among black oat families grown in different crop seasons.

\section{MATERIALS AND METHODS}

The trials were carried out at Frederico Westphalen,

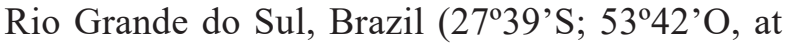

461.3 asl), from Jun to Oct in 2014 and 2015 crop season. The climate is $\mathrm{Cfa}$, described as subtropical with no defined dry season and annual average temperature is $19.6^{\circ} \mathrm{C}$, and annual rainfall is 1.398 $\mathrm{mm}$ (Alvares et al. 2013), and the soil is classified as Hapludox.

Black oat families used in this work is originated from Black Oat Breeding Program of Federal University of Santa Maria, campus Frederico Westphalen. Seventy - six black oat families and three cultivars (BRS Madrugada, BRS Centauro, BRS 139 Neblina), considered as control, were growth in two crop seasons. Families with intercalary controls experimental design was used. The sowing was carried out on Jun $14^{\text {th }}$ in 2016 crop season, and Jun $12^{\text {th }}$ in 2017 crop season. Each family was composed of a line of $3 \mathrm{~m}$ in length and the controls were seeded intercalated in three replicates. Line spacing was $0.5 \mathrm{~m}$ and density of 60 seeds per linear meter. The cultural treatments were carried out according to technical indications for crop (Lângaro and Carvalho 2014).

Traits evaluated were: days from emergence to flowering (EF), considered when $50 \%$ of plants had panicle. And when families were in physiological maturity, eight plants per family were evaluated: plant height $(\mathrm{PH}, \mathrm{cm})$, panicle length (PL, cm), number of fertile tiller (NT), panicle weight (PW, $\mathrm{g})$ panicle grain weight $(\mathrm{PGW}, \mathrm{g})$ and ratio between panicle weight and panicle grain weight (RPG).

The meteorological data were obtained from the Instituto Nacional de Meteorologia (INMET), referring to automatic weather station of Frederico Westphalen - RS (A854), located about $350 \mathrm{~m}$ from experiment, for cultivation period of 2016 (Jun $14^{\text {th }}$ 2016 to Oct $31^{\text {st }} 2016$ ) and 2017 (Jun $12^{\text {th }} 2017$ to Oct $10^{\text {th }} 2017$ ). For that, instantaneous, maximum and minimum air temperature recorded every hour was used, obtaining average for instantaneous, maximum and minimum temperature recorded for day. And for daily precipitation was carried out accumulation on a day. 
The variance analysis was performed according to families with intermediate controls experimental design (Cruz et al. 2014). Thus, families were evaluated using controls' variance components as an environmental effect.

The value of each observation for controls is given by the model of regular treatments:

$$
Y_{i j}=\mu+T_{i}+\varepsilon_{i j}
$$

Where:

$Y_{i j} Y_{i j}$ : value of trait for $\mathrm{i}$-th control in the $\mathrm{j}$-th repetition;

$\mu \mu$ : general controls average;

$T_{i} T_{i}$ : i-th controls effect $(\mathrm{i}=1,2, \ldots \mathrm{t})$;

$\varepsilon_{i j} \varepsilon_{i j}$ : random error involving controls.

And for families, considering non-regular treatments:

$$
y_{i}=\mu_{f}+F_{i}+\varepsilon_{i}
$$

Where:

$y_{i} y_{i}$ : value of trait for i-th family; $\mu_{f} \mu_{f}$ : general families average; $F_{i} F_{i}$ : i-th family effect;

$\varepsilon_{i} \varepsilon_{i}:$ random error involving families.

For controls have:

$$
\begin{array}{cc}
k=\frac{\mathrm{N}-\left(\frac{1}{\mathrm{~N}} \sum_{\mathrm{i}=1}^{\mathrm{t}} \mathrm{ri}^{2}\right)}{\mathrm{t}-1} & k=\frac{\mathrm{N}-\left(\frac{1}{\mathrm{~N}} \sum_{\mathrm{i}=1}^{\mathrm{t}} \mathrm{ri}^{2}\right)}{\mathrm{t}-1} \mathrm{e} \\
\mathrm{N}=\sum_{\mathrm{i}=1}^{\mathrm{t}} \mathrm{r}_{\mathrm{i}} & \mathrm{N}=\sum_{\mathrm{i}=1}^{\mathrm{t}} \mathrm{r}_{\mathrm{i}}
\end{array}
$$

Due to statistical model used, with families without repetitions, it is necessary to perform data correction. For this, it is admitted that there is a differential effect of environment between families, and thus, corrected from controls information (Cruz et al. 2014). After data correction, variance components and genetic parameters were estimated for controls and families.

For phenotypic, genetic and environmental correlations, covariance was estimated between two traits, and correlations were later estimated. To carry out all analyzes, was used statistical program Genes (Cruz 2016).

\section{RESULTS}

According to variance analysis, for 2016 crop season, PGW for families, and EF, PH, PL for controls revealed difference. In 2017, was observed difference for $\mathrm{PH}$ and $\mathrm{PGW}$, for families and $\mathrm{EF}$, $\mathrm{PH}$ and PGW for controls.

Temperatures observed during crop period was ideal to culture, with average of $16.2{ }^{\circ} \mathrm{C}$ and $17.5^{\circ} \mathrm{C}$ for 2016 and 2017, respectively. Highlight temperature in flowering stage (76.8 and 70.6 days after emergence), which occurred in September, for both crop seasons, a minimum, average and maximum temperature of $4.1^{\circ} \mathrm{C}, 16.3^{\circ} \mathrm{C}$ and 33.2 ${ }^{\circ} \mathrm{C}$ in 2016 and $12.8^{\circ} \mathrm{C}, 21.3{ }^{\circ} \mathrm{C}$ and $33.7^{\circ} \mathrm{C}$ in 2017. Thus, showing that there was an increase of $5{ }^{\circ} \mathrm{C}$ in the average temperature in Sept 2017 compared to Sept 2016.

Considering accumulated precipitation in crop period was observed 680.2 and $720.8 \mathrm{~mm}$ for 2016 and 2017, respectively. Difference between crop seasons in precipitation distribution was observed. In 2016 rainfall was well distributed throughout crop period. While in 2017, after sowing there was sufficient precipitation for germination and emergence, then there were 27 days without precipitation, with July accumulated of $15.8 \mathrm{~mm}$, lower than historical average for month $(130 \mathrm{~mm}$, data not shown).

In comparison to crop seasons, it should be noted that in 2017 there was a reduction of all traits studied (EF, PH, PL, NT, PW, PGW and RPG) in relation to 2016 for both families and controls (Tables I and II). This phenotypic difference is linked to meteorological conditions during oat cycle for two crop seasons (Figure 1).

As for phenotypic variance, it is verified that for both families and controls the highest variance is attributed to genetic factor (genetic variance) both 

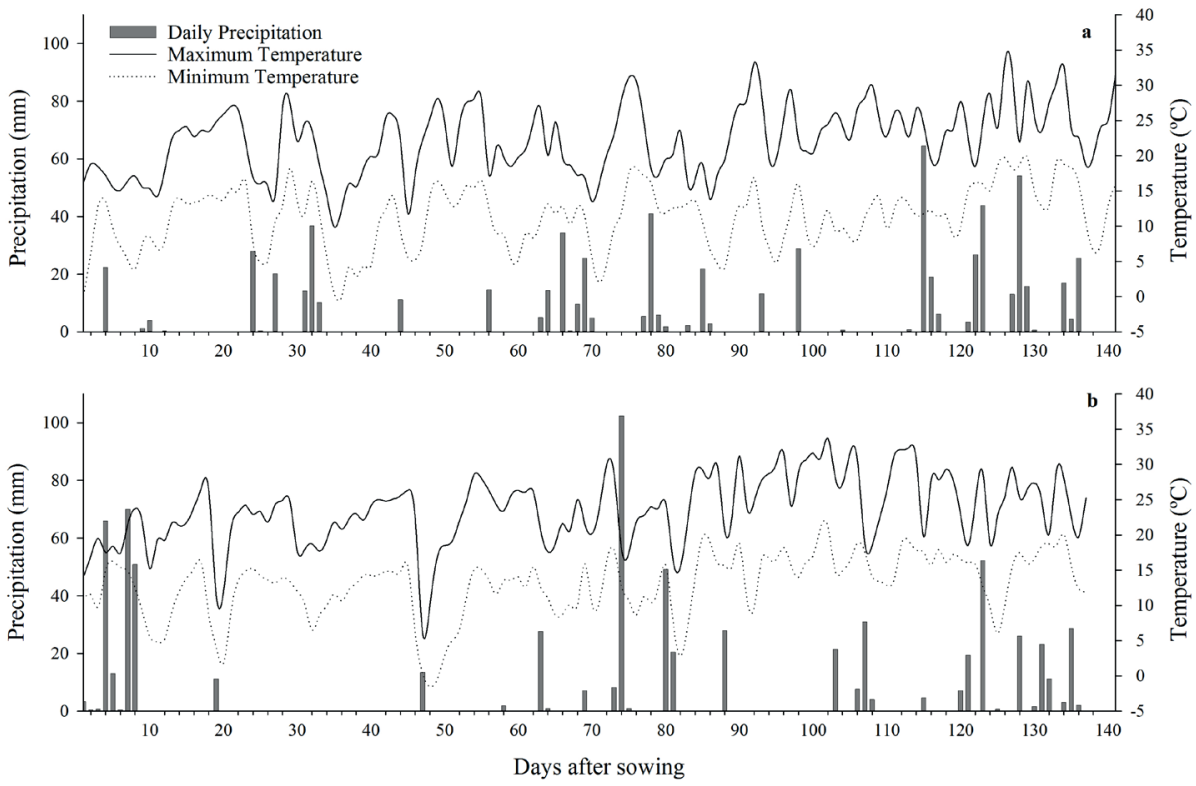

Figure 1 - Meteorological data of daily precipitation, maximum and minimum temperatures during black oat cultivation period in 2016 (a) and 2017 (b) agricultural years. Source: INMET, (Frederico Westphalen - A854) Frederico Westphalen - RS automatic weather station.

TABLE I

Variance components and genetic parameters estimated for families and controls for 2016 crop season.

\begin{tabular}{|c|c|c|c|c|c|c|c|}
\hline \multicolumn{8}{|c|}{ Families } \\
\hline Parameters & $\mathbf{E F}^{\mathbf{1}}$ & PH & PL & NT & PW & PGW & RPG \\
\hline Fenotypic variance & 9.672 & 34.431 & 5.931 & 8.955 & 0.150 & 0.104 & 0.004 \\
\hline Environmental variance & 2.000 & 7.494 & 0.888 & 3.796 & 0.012 & 0.004 & 0.001 \\
\hline Genotypic variance & 7.672 & 26.936 & 5.043 & 5.159 & 0.138 & 0.101 & 0.002 \\
\hline Heritability & 79.322 & 78.234 & 85.024 & 57.612 & 92.053 & 96.581 & 68.598 \\
\hline $\mathrm{CVg}$ & 3.628 & 3.663 & 9.625 & 20.882 & 29.351 & 34.790 & 6.949 \\
\hline Ratio CVg CVe ${ }^{-1}$ & 1.959 & 1.896 & 2.383 & 1.166 & 3.404 & 5.315 & 1.478 \\
\hline Families average & 76.36 & 141.68 & 23.33 & 10.88 & 1.27 & 0.91 & 0.71 \\
\hline CV (\%) Families & 1.85 & 1.93 & 4.04 & 17.91 & 8.62 & 6.55 & 4.70 \\
\hline \multicolumn{8}{|c|}{ Controls } \\
\hline Parameters & $\mathbf{E F}^{\mathbf{1}}$ & PH & PL & NT & PW & PGW & RPG \\
\hline Fenotypic variance & 28.037 & 86.434 & 10.198 & 13.658 & 0.020 & 0.017 & 0.001 \\
\hline Environmental variance & 0.667 & 2.498 & 0.296 & 1.265 & 0.004 & 0.001 & 0.000 \\
\hline Genotypic variance & 27.370 & 83.936 & 9.902 & 12.392 & 0.016 & 0.015 & 0.000 \\
\hline CVgt & 6.495 & 6.359 & 12.820 & 26.008 & 9.049 & 12.610 & 2.787 \\
\hline Ratio CVgt CVe ${ }^{-1}$ & 3.699 & 3.347 & 3.339 & 1.807 & 1.146 & 2.081 & 0.555 \\
\hline Controls average & 80.56 & 144.08 & 24.55 & 13.54 & 1.38 & 0.99 & 0.67 \\
\hline CV (\%) Controls & 1.76 & 1.90 & 3.84 & 14.39 & 7.90 & 6.06 & 5.02 \\
\hline
\end{tabular}

${ }^{1} \mathrm{EF}$ : days of emergence to flowering; PH: plant height; PL: panicle length; NT: number of fertile tiller; PW: panicle weight; PGW: panicle grain weight; RPG: ratio between panicle weight and panicle grain weight; CVg: coeficiente of genetic variation; CVe: coefficient of experimental variation; CVgt: coefficient of controls genetic variation; CV: coefficient of variation. 
in 2016 and 2017 (Tables I and II). PH showed the highest variance values for families and controls in crop seasons, being variable most influenced by the environmental variation.

The PGW revealed greater stability, when referring to ratio $\mathrm{CVg} \mathrm{CVe}^{-1}$, for this index compared to crop seasons, with highest values of 5.315 and 7.204 for 2016 and 2017, respectively, which could lead to more effective selection gains (Tables I and II). NT presented higher heritability amplitude, $\mathrm{CVg}$ and ratio $\mathrm{CVe} \mathrm{CVe}^{-1}$, evidencing in 2016 (Table I), most favorable meteorological conditions promoted this greater differentiation in phenotypic response of families. Controls showed same tendency as families (Tables I and II). EF phenotypic variance was higher for 2017 (Table II).

In relation to correlation, significant phenotypic correlations showed higher values of genetic correlation. EF showed significant positive phenotypic correlation with PL in 2016, and with RPG in 2017 (Table III). PH revealed positive and moderate magnitude phenotypic association with PL, PW and PGW (Table III). The relationship among PL, PW and PGW revealed significant positive and moderate magnitude phenotypic association for crop seasons (Table III). RPG is directly linked to PW and PGW, showing positivevalued, moderate to high magnitude for genetic and phenotypic correlation.

Regarding environmental correlation between traits, it is observed that associations had variation between crop seasons (Table III). Association between EF and $\mathrm{PH}$ revealed a greater environmental correlation in 2016 crop season. Whereas in 2017, association between EF and RPG was observed, evidencing that with EF reduction, consequently RPG also resulted in lower indexes.

\section{DISCUSSION}

Oat crop has a high plasticity to develop over a wide temperature range, which can vary from $0{ }^{\circ} \mathrm{C}$ to 35
${ }^{\circ} \mathrm{C}$ (Leite et al. 2012). This fact can be confirmed by analyzing meteorological data (Figure 1), in temperature and rainfall variation between 2016 and 2017 crop seasons.

Oat cycle duration varies from 118 to 120 days of emergence to physiological maturation (Carvalho et al. 2009, Oliveira et al. 2011). Winter cereals cycles grown in southern Brazil is directly influenced by photoperiod and air temperature, and the last predicts the crop cycle (Castro et al. 2012, Leite et al. 2012), and development cycle is accelerated by high temperatures.

In present work, black oat cycle was reduced in 2017 when compared to 2016 crop season. This reduction can be allied to long period without precipitation (about from 20 to 45 days after sowing, Figure 1) in the initial development stage and elevated temperature observed during oat development cycle.

It is known that species has optimum, minimum and maximum air temperature to the best development. Simulation and experiments conducted in field by Mantai et al. (2017) corroborate with these results. The authors noting for white oat minimum, optimum and maximum cardinal temperatures of 15,25 and $35{ }^{\circ} \mathrm{C}$, respectively, resulted in a reduction of nine days in cycle when compared to cardinal temperatures of 4, 22 and $30{ }^{\circ} \mathrm{C}$. For wheat, temperature increase is detrimental to grain yield (Deryng et al. 2014), and Asseng et al. (2015) emphasize that every $1{ }^{\circ} \mathrm{C}$ increase in temperature, above $31^{\circ} \mathrm{C}$, can reduces $6 \%$ in grain yield.

Despite requirement of higher temperature and low humidity in maturation stage (Castro et al. 2012), high temperatures $\left(>31^{\circ} \mathrm{C}\right.$ ) over four consecutive days at anthesis can result in reducing number of grains, grain weight and, therefore, reducing grain yield (Ferris et al. 1998). Thus, it can be highlighted that 2016 provided better meteorological conditions for oat growth and development. 
TABLE II

Variance components and genetic parameters estimated for families and controls for 2017 crop season.

\begin{tabular}{|c|c|c|c|c|c|c|c|}
\hline \multicolumn{8}{|c|}{ Families } \\
\hline Parameters & $\mathbf{E F}^{\mathbf{1}}$ & PH & PL & NT & PW & PGW & RPG \\
\hline Fenotypic variance & 9.171 & 38.173 & 3.730 & 2.070 & 0.091 & 0.065 & 0.007 \\
\hline Environmental variance & 1.013 & 1.905 & 0.859 & 0.253 & 0.005 & 0.001 & 0.003 \\
\hline Genotypic variance & 8.159 & 36.268 & 2.871 & 1.817 & 0.086 & 0.064 & 0.004 \\
\hline Heritability & 88.959 & 95.009 & 76.975 & 87.775 & 94.121 & 98.110 & 62.679 \\
\hline $\mathrm{CVg}$ & 4.101 & 4.979 & 7.744 & 34.803 & 25.955 & 35.060 & 10.245 \\
\hline Ratio CVg CVe ${ }^{-1}$ & 2.839 & 4.363 & 1.828 & 2.680 & 4.001 & 7.204 & 1.296 \\
\hline Families average & 69.66 & 120.96 & 21.88 & 3.87 & 1.13 & 0.72 & 0.64 \\
\hline CV $(\%)$ Families & 1.44 & 1.14 & 4.24 & 12.99 & 6.49 & 4.87 & 7.90 \\
\hline \multicolumn{8}{|c|}{ Controls } \\
\hline Parameters & $\mathbf{E F}^{\mathbf{1}}$ & PH & PL & NT & PW & PGW & RPG \\
\hline Fenotypic variance & 38.399 & 65.026 & 0.551 & 0.256 & 0.024 & 0.034 & 0.010 \\
\hline Environmental variance & 0.338 & 0.635 & 0.286 & 0.084 & 0.002 & 0.000 & 0.001 \\
\hline Genotypic variance & 38.061 & 64.391 & 0.265 & 0.172 & 0.023 & 0.033 & 0.010 \\
\hline CVgt & 7.824 & 6.372 & 2.311 & 13.505 & 15.580 & 33.681 & 17.485 \\
\hline Ratio CVgt CVe ${ }^{-1}$ & 6.131 & 5.814 & 0.555 & 0.824 & 2.051 & 5.205 & 1.937 \\
\hline Controls average & 78.85 & 125.94 & 22.27 & 3.07 & 0.96 & 0.54 & 0.56 \\
\hline CV (\%) Controls & 1.28 & 1.10 & 4.16 & 16.39 & 7.60 & 6.47 & 9.03 \\
\hline
\end{tabular}

${ }^{1}$ EF: days of emergence to flowering; PH: plant height; PL: panicle length; NT: number of fertile tiller; PW: panicle weight; PGW: panicle grain weight; RPG: ratio between panicle weight and panicle grain weight; CVg: coeficiente of genetic variation; CVe: coefficient of experimental variation; CVgt: coefficient of controls genetic variation; CV: coefficient of variation.

It was highlighted that PGW can be used to select superior genotypes, and reach effective genetic gains. Kurek et al. (2002), in research with white oat, due to high coefficients observed suggests that panicle weight is used as a selection criterion, due to practicality of obtaining this trait.

In present study, higher phenotypic variance in 2017 to EF, can be justified by meteorological conditions, in the face of water availability and higher average temperature (Figure 1). Controls showed a shorter time between emergence and flowering, but this reduction was smaller. The lower influence on EF in controls, showing cultivars presented greater stability than the families studied.

Differences observed in genetic parameters, phenotypic and genetic correlations between traits showed similar values for two crop seasons (Table III). Moreover, significant phenotypic correlations showed higher values of genetic correlation.

Phenotypic correlation showed between EF and PL in 2016, and EF and RPG in 2017, can be explained to vegetative period and longer cycle provide greater potential for photoassimilates production and accumulation, therefore, potentiating biomass accumulation (Lehmen et al. 2014) and grain yield (Ferris et al. 1998).

Noting the association among PL, PW and PGW, are important factor for a black oat breeding program, because PL is easy to measure. Vasconcelos et al. (2016), emphasize that the relation of grain weight and bark weight are aspects relevant to oat breeding. Panicle weight may be 
TABLE III

Estimatives of phenotypic $\left(r_{p}\right)$, genetic $\left(r_{G}\right)$ and environmental $\left(r_{E}\right)$ correlations between seven morphological traits in black oat families evaluated in 2016 (upper diagonal) and 2017 (inferior diagonal) crop seasons.

\begin{tabular}{|c|c|c|c|c|c|c|c|c|}
\hline \multicolumn{2}{|c|}{ Trait } & \multirow{2}{*}{$\begin{array}{c}\mathbf{E F}^{\mathbf{1}} \\
-\end{array}$} & \multirow{2}{*}{$\frac{\mathbf{P H}}{-0.08}$} & \multirow{2}{*}{$\frac{\mathbf{P L}}{0.30 * *}$} & \multirow{2}{*}{$\frac{\text { NT }}{-0.08}$} & \multirow{2}{*}{$\frac{\mathbf{P W}}{0.21}$} & \multirow{2}{*}{$\begin{array}{c}\text { PGW } \\
0.18\end{array}$} & \multirow{2}{*}{$\frac{\text { RPG }}{-0.01}$} \\
\hline & $r_{P}$ & & & & & & & \\
\hline \multirow[t]{3}{*}{$\mathrm{EF}^{1}$} & $r_{G}$ & - & -0.32 & 0.29 & 0.05 & 0.30 & 0.21 & -0.05 \\
\hline & $r_{E}$ & - & 0.83 & 0.36 & -0.39 & -0.35 & -0.07 & 0.12 \\
\hline & $r_{P}$ & 0.00 & - & $0.48^{* *}$ & 0.19 & $0.40^{* *}$ & $0.36^{* *}$ & 0.02 \\
\hline \multirow[t]{3}{*}{$\mathrm{PH}$} & $r_{G}$ & -0.06 & - & 0.41 & 0.36 & 0.46 & 0.44 & -0.15 \\
\hline & $r_{E}$ & 0.67 & - & 0.79 & -0.18 & 0.06 & -0.22 & 0.51 \\
\hline & $r_{P}$ & 0.15 & $0.52 * *$ & - & -0.17 & $0.62 * *$ & $0.54 * *$ & 0.03 \\
\hline \multirow[t]{3}{*}{ PL } & $r_{G}$ & 0.19 & 0.60 & - & -0.27 & 0.66 & 0.61 & -0.20 \\
\hline & $r_{E}$ & -0.03 & 0.06 & - & 0.05 & 0.38 & -0.17 & 0.83 \\
\hline & $r_{P}$ & -0.09 & $-0.37 * *$ & -0.17 & - & -0.07 & -0.08 & -0.14 \\
\hline \multirow[t]{3}{*}{ NT } & $r_{G}$ & -0.07 & -0.40 & -0.18 & - & -0.29 & -0.21 & -0.32 \\
\hline & $r_{E}$ & -0.27 & 0.01 & -0.11 & - & 0.76 & 0.63 & 0.16 \\
\hline & $r_{P}$ & 0.18 & $0.33 * *$ & $0.50 * *$ & -0.02 & - & $0.98 * *$ & $0.49^{* *}$ \\
\hline \multirow[t]{3}{*}{ PW } & $r_{G}$ & 0.15 & 0.32 & 0.55 & -0.05 & - & 1.03 & 0.51 \\
\hline & $r_{E}$ & 0.51 & 0.46 & 0.27 & 0.34 & - & 0.21 & 0.57 \\
\hline & $r_{P}$ & 0.21 & 0.18 & $0.43 * *$ & 0.03 & $0.95 * *$ & - & $0.65^{* *}$ \\
\hline \multirow[t]{3}{*}{ PGW } & $r_{G}$ & 0.19 & 0.17 & 0.49 & 0.06 & 0.98 & - & 0.78 \\
\hline & $r_{E}$ & 0.65 & 0.42 & 0.03 & -0.54 & 0.27 & - & 0.10 \\
\hline & $r_{P}$ & $0.26^{*}$ & -0.07 & 0.21 & 0.06 & $0.47 * *$ & $0.67 * *$ & - \\
\hline \multirow[t]{2}{*}{ RPG } & $r_{G}$ & 0.10 & -0.21 & 0.18 & 0.14 & 0.49 & 0.83 & - \\
\hline & $r_{E}$ & 0.89 & 0.62 & 0.30 & -0.20 & 0.62 & 0.38 & - \\
\hline
\end{tabular}

**, *Significative to $t$ test $(p<0.01$ and $p<0.05)$. ${ }^{1} \mathrm{EF}$ : days of emergence to flowering; PH: plant height; PL: panicle length; NT: number of fertile tiller; PW: panicle weight; PGW: panicle grain weight; RPG: ratio between panicle weight and panicle grain weight.

more efficient in eliminating low yield genotypes in selecting superior genotypes by eliminating lighter panicles (Chapko and Brinkman 1991).

As already pointed out, due to meteorological conditions in 2017 most of associations revealed greater environmental influence. Environmental correlation confirms above statements, that there was an environmental influence in crop season, especially in 2017 (Table III).
Genetic correlations, inheritable fraction, can be caused by pleiotropic effects and/or gene link, and may still have changes due to environmental correlations, varying from year to year or by crop management (Falconer and Mackay 1996). In addition, to environmental variation between crop seasons, there is variation due to the application of fungicide, which influences agronomic traits in white oat (Benin et al. 2005). In this way, due to the 
environmental influence on traits, selection in more crop seasons and locals are essential.

\section{CONCLUSION}

Variance observed between families and controls, emphasize that families studied have potential to compose a breeding program. Variance components expressed greater genetic variance for crop seasons. Panicle weight and panicle grain weight presented high heritability and, these are correlated with panicle length. Thus, these traits can be used to select superior genotypes. Divergent meteorological conditions between crop seasons expressed little variation between phenotypic, genetic and environmental correlations, but did not alter magnitude and sense of phenotypic and genetic correlations.

\section{ACKNOWLEDGMENTS}

We acknowledge Coordenação de Aperfeiçoamento de Pessoal de Nível Superior (CAPES) for granting the scholarship.

\section{AUTHOR CONTRIBUTIONS}

DM and CM performed data collection, wrote and organized the manuscript; TO and MN, performed data analysis, wrote and organized the manuscript; AR, LAK performed data collection; BOC, VSM, VQS were the advisors, critically revised the manuscript and approved the final version.

\section{REFERENCES}

ALVARES CA, STAPE JL, SENTELHAS PC, DE MORAES G, LEONARDO J AND SPAROVEK G. 2013. Köppen's climate classification map for Brazil. Meteorol Z 22: 711728.

ASSENG S ET AL. 2015. Rising temperatures reduce global wheat production. Nature Climate Change 5: 143-147.

BENIN G, HARTWIG I, CARVALHO FIF, OLIVEIRA AC, VIEIRA EA, BERTAN I, SILVA JA, VALÉRIO IP AND RIBEIRO G. 2005. Repeatability estimates of genetic, phenotypic and environmental correlations in oats with and without fungicide application. Crop Breed Appl Biotechnol 5: 183-190.

BENNETT D, IZANLOO A, REYNOLDS M, KUCHEL H, LANGRIDGE P AND SCHNURBUSCH T. 2012. Genetic dissection of grain yield and physical grain quality in bread wheat (Triticum aestivum L.) under water limited environments. Theor Appl Genet 125: 255-271.

CARVALHO FIF, OLIVEIRA AC, VALÉRIO IP, BENIN G, SCHMIDT DAM, HARTWIG I, RIBEIRO G AND SILVEIRA G. 2009. Barbarasul: A high-yielding and lodging-resistant white oat cultivar. Crop Breed Appl Biotechnol 9: 96-99.

CASTRO GSA, COSTA CHM AND FERRARI NETO J 2012. Ecofisiologia da aveia branca. Sci Agrar Paran 11: 1-15.

CHAPKO LBAND BRINKMAN MA. 1991. Interrelationships between panicle weight, grain yield and grain yield components in oat. Crop Sci 31: 878-882.

CRUZ CD. 2016. Genes Software - extended and integrated with the R, Matlab and Selegen. Acta Sci Agron 38: 547552.

CRUZ CD, CARNEIRO PCS AND REGAZZI AJ. 2014. Modelos biométricos aplicados ao melhoramento genético. Editora UFV, Viçosa, 668 p.

DERYNG D, CONWAY D, RAMANKUTTY N, PRICE J AND WARREN R. 2014. Global crop yield response to extreme heat stress under multiple climate change futures. Environ Res Lett 9: 1-13.

FALCONER DS AND MACKAY TFC. 1996. Introduction to quantitative genetics. $4^{\text {th }}$ ed., Edinburgh: Longman Group Limited, $464 \mathrm{p}$.

FERRIS R, ELLIS RH, WHEEELER TR AND HADLEY P. 1998. Effect of high temperature stress at anthesis on grain yield and biomass of field grown crops of wheat. Plant Cell Environ 34: 67-78.

KUREK AJ, CARVALHO FIF, OLIVEIRA AC, CARGNIN A, MARCHIORO VS AND LORENCETTI C. 2002. Coeficiente de correlação entre caracteres agronômicos e de qualidade do grão e sua utilidade na seleção de plantas em aveia. Ciênc Rural 32: 371-376.

LÂNGARO NC AND CARVALHO IQ (Orgs). 2014. Indicações técnicas para a cultura da aveia: XXXIV Reunião da Comissão Brasileira de Pesquisa de Aveia Fundação ABC. Passo Fundo: Ed. Universidade de Passo Fundo, $136 \mathrm{p}$.

LEHMEN RI, FONTANELI RS, FONTANELI RS AND SANTOS HP. 2014. Rendimento, valor nutritivo e características fermentativas de silagens de cerais de inverno. Ciênc Rural 44: 1180-1185.

LEITE JGDB, FEDERIZZI LC AND BERGAMASCHI H. 2012. Mudanças climáticas e seus possíveis impactos aos sistemas agrícolas no Sul do Brasil. Rev Bras Cienc Agrar 7: $337-343$

MANTAI RD, SILVA JAG, MAROLLI A, MAMANN1 ÂTW, SAWICKI1 S AND KRÜGER CAMB. 2017. Simulation 
of oat development cycle by photoperiod and temperature. R Bras Eng Agríc Ambiental 21: 3-8.

OLIVEIRA AC, CRESTANI M, CARVALHO FIF, SILVA JAG, VALÉRIO IP, HARTWIG I, BENIN G, SCHMIDT DAM AND BERTAN I. 2011. Brisasul: A new highyielding white oat cultivar with reduced lodging. Crop Breed Appl Biotechnol 11: 370-374.

PEREIRA MG AND AMARAL JR AT. 2001. Estimation of Genetic Components in Popcorn Based on the Nested Design. Crop Breed Appl Biotechnol 1: 3-10.
REBETZKE GJ, CHENU K, BIDDULPH B, MOELLER C, DEERY DM, RATTEY AR, BENNETT D, BARRETTLENNARD EG AND MAYER JE. 2012. A multisite managed environment facility for targeted trait and germplasm phenotyping. Func Plant Biology 40: 1-13.

VASCONCELOS ES, HOEPERS LML, AMARAL RG, EGEWARTH VA AND STRENSKE A. 2016. Genetic parameters and productivity of quinoa in western Paraná State, Brazil. Acta Sci Agron 38: 185-191. 